\title{
Glosa do wyroku Sądu Najwyższego z dnia 8 maja 2019 r., V CSK 207/18
}

\author{
Comment to the Supreme Court judgment of 8th May 2019, V CSK 208/18 \\ Комментарий к постановлению Верховного Суда от 8 мая 2019 года, V CSK 207/18
}

\author{
KRZYSZTOF ŻOK \\ Dr, Uniwersytet im. Adama Mickiewicza w Poznaniu \\ e-mail: krzysztof.zok@amu.edu.pl, https://orcid.org/0000-0002-9407-5307
}

\begin{abstract}
Streszczenie: Glosa analizuje wpływ niedawnego wyroku Sądu Najwyższego, w którym ustalono nowe wskazania dotyczące podstawy odpowiedzialności członka zarządu. Zgodnie z tym orzeczeniem syndyk może żądać naprawienia szkody $w$ ramach odpowiedzialności kontraktowej przez dochodzenie roszczenia przewidzianego w art. 293 Kodeksu spółek handlowych. Wniosek ten istotnie różni się od przyjętego wcześniej stanowiska. Dotychczas bowiem sądy uznawały, że syndyk, jako osoba trzecia, może żądać odszkodowania tylko w ramach odpowiedzialności deliktowej. Rozważania w omawianym wyroku skupiają na kwestii uchwały wspólników niezbędnej do żądania odszkodowania. Niemniej pogłębiona analiza tego orzeczenia ujawnia dalej idące konsekwencje tego rozstrzygnięcia. W glosie podnosi się w szczególności, że nowe wskazania mogą oddziaływać na klasę zachowań powodujących powstanie odpowiedzialności członka zarządu, a także wpływać na termin przedawnienia.
\end{abstract}

Słowa kluczowe: prawo spółek handlowych, odpowiedzialność członków zarządu, odpowiedzialność kontraktowa, odpowiedzialność deliktowa

Summary: The following paper examines the impact of the recent Supreme Court judgment which established new guidelines regarding the basis of director liability. According to the ruling, the receiver (syndyk) may demand damages under contractual liability by pursuing a claim provided for in art. 293 of Polish Company Code. This conclusion differs significantly from the previously adopted position. Until now, the courts have held that the receiver, as a third party, can demand compensation only under tort liability. The considerations in the discussed judgment are focused on the question of the shareholders' resolution necessary to claim damages. However, a more thorough analysis reveals the far-reaching consequences of the ruling. In particular, the paper argues that the new guidelines may affect the class of behaviour which may give rise to director liability as well as the limitation period for damage claims.

Key words: company law, director liability, contractual liability, tort liability

Резюме: Комментарий анализирует влияние недавнего постановления Верховного Суда, в котором были установлены новые признаки, касающиеся основания ответственности члена совета директоров. Согласно этому постановлению, внешний управляющий может требовать возмещения убытков в рамках договорной ответственности путем предъявления требования, предусмотренного статьей 293 Кодекса хозяйственных товариществ и обществ. Этот вывод существенно отличается от ранее принятой позиции. Ранее суды считали, что внешний управляющий, как третья сторона, может требовать компенсации только в рамках деликтной ответственности. Рассуждения в обсуждаемом постановлении сосредоточены на вопросе решения акционеров, необходимого для требования возмещения убытков. Однако более

1 Wyrok SN z dnia 8 maja 2019 r., V CSK 207/18, OSNC-ZD 2020, nr 3, poz. 46, Legalis nr 1972832. Publikacja powstała w ramach stażu naukowego sfinansowanego w drodze konkursu ze środków Wydziału Prawa i Administracji Uniwersytetu im. Adama Mickiewicza w Poznaniu. 
глубокий анализ судебного постановления выявляет более далеко идущие его последствия. В заключении, в частности, утверждается, что новые указания могут повлиять на класс поведений, влекущих за собой ответственность члена совета директоров, а также влиять на срок исковой давности.

Ключевые слова: право хозяйственных товариществ и обществ, ответственность членов совета директоров, договорная ответственность, деликтная ответственность

Glosowany wyrok porusza interesujące zagadnienie żądania przez syndyka naprawienia szkody wyrządzonej spółce w wyniku działania albo zaniechania członka zarządu. Trzeba przy tym zaznaczyć, że stanowisko wyrażone w omawianym orzeczeniu odbiega od poglądu prezentowanego wcześniej w judykaturze². Wymienione rozstrzygnięcie zasługuje zatem niewątpliwie na uwagę; tym bardziej że spotkało się już z aprobatą $\mathrm{w}$ doktrynie i orzecznictwie ${ }^{3}$. Wypowiedzi te koncentrują się wokół legitymacji syndyka, co jest w pełni zrozumiałe, biorąc pod uwagę fakt, że kwestia ta stanowiła główny przedmiot rozważań Sądu Najwyższego w wyroku z dnia 8 maja 2019 r. Celem niniejszego opracowania jest natomiast zwrócenie uwagi na konsekwencje poglądu zawartego w omawianym rozstrzygnięciu. Znaczenie powołanego orzeczenia wykracza bowiem poza przesądzenie legitymacji syndyka do dochodzenia naprawienia szkody wyrządzonej spółce przez członka zarządu.

Stan faktyczny w glosowanym orzeczeniu nie był skomplikowany i przedstawiał się następująco:

Syndyk masy upadłościowej spółki z ograniczoną odpowiedzialnością wystąpił z powództwem z art. 293 K.s.h. przeciwko byłemu członkowi zarządu, domagając

2 Zob. wyrok SO w Olsztynie z dnia 15 czerwca 2018 r., V GC 63/15, Legalis nr 1986469; wyrok SA w Białymstoku z dnia 8 czerwca 2018 r., I AGa 88/18, Legalis nr 1830549; wyrok SA w Katowicach z dnia 6 grudnia 2017 r., V ACa 712/17, Legalis nr 1712719; wyrok SA w Białymstoku z dnia 17 lutego 2017 r., I ACa 746/16, Legalis nr 1581308. Zob. wyrok SN z dnia 8 listopada 2018 r., II CSK 587/17, Legalis nr 1847119, w którym nie zakwestionowano dochodzenia przez syndyka w ramach reżimu odpowiedzialności deliktowej naprawienia szkody wyrządzonej spółce przez członka zarządu.

3 W orzecznictwie: wyrok SA w Warszawie z dnia 9 września 2019 r., V ACa 289/19, Legalis nr 2271404. W literaturze: P. Popardowski, O spółkach handlowych w najnowszym orzecznictwie Sądu Najwyższego - przegląd orzecznictwa, Glosa 2019, nr 4, s. 10-14; T. Szczurowski, w: Kodeks spótek handlowych, red. Z. Jara, 2020, art. 293, Nb. 11 [baza danych Legalis]. 
się zapłaty określonej kwoty tytułem naprawienia szkody wyrządzonej spółce4. Sąd Okręgowy uwzględnił powyższe powództwo, zasądzając jednak odszkodowanie na podstawie art. 415 K.c. ${ }^{5}$. W uzasadnieniu sąd I instancji wyjaśnił, że uzyskanie uchwały, o której mowa w art. 228 pkt 2 K.s.h., było w niniejszej sprawie niemożliwe, co z kolei wykluczało dochodzenie naprawienia szkody na mocy art. 293 K.s.h. Niemniej żądanie powoda okazało się zasadne w świetle art. 415 K.c.

Sąd II instancji oddalił apelację pozwanego, podnosząc, że podstawa prawna wskazana przez powoda nie jest wiążąca dla składu orzekającego. Możliwe było więc zasądzenie odszkodowania na mocy art. 415 K.c. w zw. z art. 300 K.s.h., nawet jeżeli syndyk wywodził swoje roszczenie z art. 293 K.s.h. Sąd Apelacyjny dodał zarazem, że upadła spółka traci w świetle art. 75 ust. 1 ustawy - Prawo upadłościowe prawo zarządu swoim majątkiem, co wyklucza podjęcie uchwały z art. 228 pkt 2 K.s.h. i w konsekwencji dochodzenie przez syndyka naprawienia szkody na podstawie art. 293 K.s.h. ${ }^{6}$. Syndyk jest przy tym zobowiązany na mocy art. 311 ust. 1 ustawy - Prawo upadłościowe do likwidacji majątku upadłej spółki. Dochodzi on wprawdzie odszkodowania dla upadłej, lecz w rzeczywistości jego działania podejmowane są $\mathrm{w}$ interesie wierzycieli spółki. Tym samym syndyk jest osobą trzecią w rozumieniu art. 300 K.s.h., wobec czego może domagać się naprawienia szkody na podstawie art. 415 K.c.

Na skutek skargi kasacyjnej wniesionej przez pozwanego Sąd Najwyższy uchylił zaskarżony wyrok i przekazał sprawę sądowi II instancji do ponownego rozpatrzenia. W uzasadnieniu Sąd Najwyższy wyjaśnił, że mimo ogłoszenia upadłości spółka pozostaje nadal stroną stosunku prawnego, z którego wynikał spór. Syndyk prowadzi przy tym postępowanie we własnym imieniu, choć na rzecz upadłej. Dlatego nie można go traktować jako osoby trzeciej w rozumieniu art. 300 K.s.h. Wykluczone jest zatem zasądzenie odszkodowania na podstawie art. 415 K.c. w zw. z art. 293 K.s.h., mimo że syndyk wywodził swoje roszczenie z art. 293 K.s.h. Sąd Najwyższy zauważył ponadto, że syndyk nie musi legitymować się uchwałą z art. 228 pkt 2 K.s.h., gdyż ograniczenia korporacyjne dotyczące zarządzania majątkiem spółki nie odnoszą się do upadłości likwidacyjnej.

4 Ustawa z dnia 15 września 2000 r. - Kodeks spółek handlowych, tekst jednolity: Dz. U. z 2019 r. poz. $505 \mathrm{z}$ późn. zm. (dalej: K.s.h.).

5 Ustawa z dnia 23 kwietnia 1964 r. - Kodeks cywilny, tekst jednolity: Dz. U. z 2019 r. poz. 1145 z późn. zm. (dalej: K.c.).

6 Ustawa z dnia 28 lutego 2003 r. - Prawo upadłościowe, tekst jednolity: Dz. U. z 2019 r., poz. 498 z późn. zm. (dalej: ustawa - Prawo upadłościowe). 
II.

W glosowanym orzeczeniu Sąd Najwyższy trafnie zauważył, że art. 293 K.s.h. dotyczy odpowiedzialności kontraktowej członka zarządu za szkodę wyrządzoną spółce działaniem albo zaniechaniem sprzecznym z prawem lub umową spółki. Stanowisko to pozostaje $\mathrm{w}$ zgodzie $\mathrm{z}$ wcześniejszymi wypowiedziami prezentowanymi w judykaturze ${ }^{7}$. Nie budzi ono także zastrzeżeń w doktrynie ${ }^{8}$. Powołanie członka zarządu skutkuje bowiem nawiązaniem między nim i spółką stosunku organizacyjnego, który można zakwalifikować jako zobowiązanie. Naruszenie obowiązków składających się na treść tego stosunku rodzi zatem odpowiedzialność cywilnoprawną ex contractu.

Nie ulega ponadto wątpliwości w świetle art. 293 K.s.h., że spółka jest podmiotem legitymowanym do żądania naprawienia szkody. Powstaje natomiast pytanie, czy syndyk upadłej spółki może dochodzić roszczenia przewidzianego w tym przepisie. Przed wydaniem glosowanego wyroku w judykaturze udzielano w tej mierze odpowiedzi negatywnej. Na poparcie powyższego stanowiska przedstawiano te same wywody, które Sąd Najwyższy zakwestionował w omawianym orzeczeniu. Można zatem w tej mierze wyróżnić dwa główne argumenty.

Pierwszy odwoływał się do niemożności podjęcia uchwały z art. 228 pkt 2 K.s.h. po ogłoszeniu upadłości spółki z ograniczoną odpowiedzialnością9. Trzeba mieć bowiem na uwadze, że w orzecznictwie konsekwentnie przyjmowano,

7 Wyrok SA w Warszawie z dnia 9 września 2019 r., V ACa 289/19, Legalis nr 2271404; wyrok SO w Szczecinie z dnia 15 maja 2019 r., VIII GC 551/13, Legalis nr 2188793; wyrok SN z dnia 8 listopada 2018 r., II CSK 587/17, Legalis nr 1847119; wyrok SA w Gdańsku z dnia 28 marca 2017 r., I ACa 782/16, Legalis nr 1674047; wyrok SO w Poznaniu z dnia 5 października 2016 r., XIV C 258/16, Legalis nr 2114055; wyrok SO w Warszawie z dnia 15 marca 2016 r., XXVI GC 1094/14, Legalis nr 2130955; wyrok SO w Olsztynie z dnia 27 lipca 2017 r., V GC 64/15, Legalis nr 1984522; wyrok SA w Szczecinie z dnia 30 marca 2015 r., I ACa 825/14, Legalis nr 1327299; wyrok SA w Warszawie z dnia 19 kwietnia 2013 r., VI ACa 1342/12, Legalis nr 722849; wyrok SN z dnia 24 września 2008 r., II CSK 118/08, OSNC 2009, nr 9, poz. 131 z glosą aprobującą K. Bilewskiej, Odpowiedzialność odszkodowawcza członków zarządu spółki z o.o. jako odpowiedzialność ex contractu, Monitor Prawniczy 2009, nr 19, s. 1070-1073. Podobnie wyrok SA w Krakowie z dnia 12 stycznia 2016 r., I ACa 1413/15, Legalis nr 1435325.

8 Zob. A. Kidyba, Kodeks spótek handlowych, t. 1. Komentarz do art. 1-300, Warszawa 2020, s. 1472; A. Opalski, w: Kodeks spółek handlowych, t. 2b. Spółka z ograniczonq odpowiedzialnością. Komentarz. Art. 227-300, red. A. Opalski, Warszawa 2018, s. 1098; A. Szajkowski, M. Tarska, w: S. Sołtysiński i in., Kodeks spótek handlowych, t. 2. Spótka z ograniczona odpowiedzialnością. Komentarz do artykułów 151-399, Warszawa 2014, s. 930; T. Szczurowski, Kodeks spółek..., 2020, art. 293, Nb. 5 [baza danych Legalis]. Odmiennie M. Radwan-Röhrenschef, Odpowiedzialność cywilnoprawna członków zarządu spółek kapitałowych, Monitor Prawniczy 1999, nr 6, s. 17.

9 Wyrok SA w Katowicach z dnia 6 grudnia 2017 r., V ACa 712/17, Legalis nr 1712719. 
iż brak wspomnianej uchwały prowadzi do oddalenia powództwa ${ }^{10}$. Tym samym uważano, że de lege lata syndyk nie jest w stanie spełnić wymogu, od którego zależy wydanie pozytywnego z jego perspektywy wyroku. Warto jednak zauważyć, że w wyroku z dnia 12 stycznia 2016 r. Sąd Apelacyjny w Krakowie uwzględnił powództwo syndyka oparte na wymienionym przepisie, nie uzasadniając jednak $\mathrm{w}$ tym zakresie szerzej swojego stanowiska ${ }^{11}$. W konsekwencji trudno jest jednoznacznie stwierdzić, czy wspomniana uchwała została podjęta, czy też skład orzekający uznał dysponowanie taką uchwałą przez syndyka za zbyteczne.

Abstrahując od tej wątpliwości, należy wskazać, że podjęcie uchwały z art. 228 pkt 2 K.s.h. uważa się w literaturze za teoretycznie możliwe także po ogłoszeniu upadłości spółki ${ }^{12}$. Zdarzenie to nie skutkuje bowiem likwidacją zgromadzenia wspólników jako organu tej osoby prawnej. Niemniej słusznie podkreśla się, że podjęcie omawianej uchwały po ogłoszeniu upadłości spółki nierzadko okaże się utrudnione ${ }^{13}$. Wątpliwość ta została dostrzeżona w glosowanym orzeczeniu. Sąd Najwyższy stwierdził bowiem, że na mocy art. 75 ust. 1 ustawy - Prawo upadłościowe zgromadzenie wspólników traci kompetencję do podjęcia uchwały z art. 228 pkt 2 K.s.h., wobec czego uzyskanie takiego aktu przez syndyka nie jest konieczne do dochodzenia naprawienia szkody wyrządzonej spółce przez członka zarządu. $\mathrm{Z}$ tej perspektywy analizowany wyrok usuwa zatem potencjalną przeszkodę $\mathrm{w}$ dochodzeniu naprawienia szkody od członka zarządu. Brak konieczności podjęcia uchwały z art. 228 pkt 2 K.s.h. należy co do zasady ocenić pozytywnie, mając na uwadze także szerszą krytykę tego wymogu, wyrażaną poza szczegółowym kontekstem żądania przez syndyka naprawienia szkody wyrządzonej spółce ${ }^{14}$. Warto również w tym miejscu zauważyć, że w literaturze odmiennie uzasadniano brak

10 Wyrok SO w Szczecinie z dnia 15 maja 2019 r., VIII GC 551/13, Legalis nr 2188793; wyrok SO w Rzeszowie z dnia 7 marca 2019 r., VI GC 323/18, Legalis nr 2117669; wyrok SO w Olsztynie z dnia 15 czerwca 2018 r., V GC 63/15, Legalis nr 1986469; wyrok SR w Bydgoszczy z dnia 23 maja 2018 r., VIII GC 235/18, Legalis nr 2001883; wyrok SA w Poznaniu z dnia 6 lipca 2017 r., I ACa 420/14, Legalis nr 2288444; wyrok SA w Białymstoku z dnia 17 lutego 2017 r., I ACa 746/16, Legalis nr 1581308; wyrok SO w Gliwicach z dnia 26 maja 2015 r., X GC 310/14, Legalis nr 2039268; wyrok SO w Warszawie z dnia 14 maja 2015 r., XXIII Ga 2281/14, Legalis nr 2130696; wyrok SN z dnia 15 kwietnia 2015 r., IV CSK 417/14, Legalis nr 1285385; wyrok SA w Szczecinie z dnia 30 marca 2015 r., I ACa 825/14, Legalis nr 1327299; wyrok SA w Łodzi z dnia 23 października 2014 r., I ACa 749/14, Legalis nr 1164242; wyrok SO w Olsztynie z dnia 24 lutego 2014 r., I C 722/13, Legalis nr 1984757; wyrok SA w Gdańsku z dnia 13 lutego 2014 r., V ACa 801/13, Legalis nr 895308; wyrok SN z dnia 4 czerwca 2012 r., I CSK 635/11, Legalis nr 549948.

11 Wyrok SA w Krakowie z dnia 12 stycznia 2016 r., I ACa 1413/15, Legalis nr 1435325.

12 T. Szczurowski, Kodeks spótek..., 2020, art. 293, Nb. 11 [baza danych Legalis].

13 Tamże.

14 R. Pabis, w: J. Bieniak i in., Kodeks spótek handlowych. Komentarz, Warszawa 2017, s. 62. 
wymogu uzyskania wspomnianej uchwały ${ }^{15}$. Wskazano mianowicie, że syndyk pozostaje formalnie stroną postępowania i działa we własnym imieniu, wobec czego art. 228 pkt 2 K.s.h. nie znajduje do niego zastosowania.

Drugi argument opierał się natomiast na wniosku, zgodnie z którym syndyk działa także w interesie wierzycieli spółki, wobec czego jest osobą trzecią w rozumieniu art. 300 K.s.h. ${ }^{16}$. Pogląd ten spotkał się jednak z krytyką w glosowanym wyroku. Sąd Najwyższy przyjął bowiem, że upadła spółka pozostaje nadal stroną postępowania w znaczeniu materialnym. Konsekwentnie zatem w ocenie składu orzekającego syndyk nie powinien być kwalifikowany jako osoba trzecia w rozumieniu powołanego przepisu. Sąd Najwyższy podkreślił zarazem, że art. 300 K.s.h. nie znajduje zastosowania do syndyka. Spostrzeżenie to jest istotne z perspektywy dalszych rozważań.

III.

Stanowisko przyjęte w orzecznictwie przed wydaniem wyroku z dnia 8 maja $2019 \mathrm{r}$. nie pozbawiało zupełnie syndyka możliwości domagania się naprawienia szkody wyrządzonej spółce przez członka zarządu. Uznanie syndyka za osobę trzecią w rozumieniu art. 300 K.s.h. pozwalało bowiem wywodzić roszczenie odszkodowawcze z art. 415 K.c., na co zresztą składy orzekające powoływały się stosunkowo często. Zmiana podstawy prawnej rozstrzygnięcia mogła przy tym wydawać się neutralna, skoro ostatecznie uszczerbek doznany w wyniku nieprawidłowego zachowania członka zarządu został wyrównany. Jak można przypuszczać, taka konstrukcja umożliwiała również sądom reagowanie na przypadki oczywiście błędnego działania albo zaniechania wymienionego piastuna organu spółki, bez wikłania się w trudności związane z uzyskaniem uchwały z art. 228 pkt 2 K.s.h. Niemniej warto - moim zdaniem - zauważyć, że mimo zasadniczo odmiennej argumentacji prawnej, zarówno przed wydaniem wyroku z dnia 8 maja 2019 r., jak i po jego wydaniu, podjęcie wspomnianej uchwały de facto nie ograniczało i nie ogranicza syndyka w możliwości dochodzenia naprawienia szkody wyrządzonej spółce przez członka zarządu. Doniosłość glosowanego orzeczenia zaznacza się natomiast im-

15 T. Szczurowski, Kodeks spółek..., 2020, art. 293, Nb. 11 [baza danych Legalis].

16 Wyrok SO w Olsztynie z dnia 15 czerwca 2018 r., V GC 63/15, Legalis nr 1986469; wyrok SA w Białymstoku z dnia 8 czerwca 2018 r., I AGa 88/18, Legalis nr 1830549; wyrok SA w Katowicach z dnia 6 grudnia 2017 r., V ACa 712/17, Legalis nr 1712719; wyrok SA w Białymstoku z dnia 17 lutego 2017 r., I ACa 746/16, Legalis nr 1581308. 
plicite w zmianie podstawy prawnej roszczenia odszkodowawczego realizowanego przez syndyka.

Trzeba bowiem zaznaczyć, że roszczenie z art. 415 K.c. w zw. z art. 300 K.s.h. w odróżnieniu od roszczenia $\mathrm{z}$ art. 293 K.s.h. - realizowane jest $\mathrm{w}$ ramach odpowiedzialności deliktowej, a nie odpowiedzialności kontraktowej. Między wspomnianymi reżimami zachodzą natomiast istotne różnice. Kwestia ta została tymczasem tylko częściowo dostrzeżona w judykaturze. Zarówno w glosowanym wyroku, jak i w innych orzeczeniach wskazywano bowiem słusznie, że w art. 293 K.s.h., podobnie jak w art. 471 K.c., ustawodawca zmienia na korzyść wierzyciela (spółki) rozkład ciężaru dowodu w zakresie winy dłużnika (członka zarządu ${ }^{17}$. Nie negując tego spostrzeżenia, trzeba jednak w mojej ocenie podkreślić, że nie jest to jedyna różnica między roszczeniem z art. 293 K.s.h. oraz roszczeniem z art. 415 K.c. w zw. z art. 300 K.s.h.

Należy w tej mierze zwrócić uwagę na bezprawność zachowania członka zarządu. W glosowanym orzeczeniu trafnie wskazano, że naruszenie stosunku organizacyjnego przez wspomnianego piastuna organu spółki może być również zakwalifikowane jako czyn niedozwolony. Stwierdzenie to należy uznać za bezsporne, gdyż powyższa konkluzja była już wcześniej podzielana w judykaturze ${ }^{18}$. Podobnie

17 Wyrok SA w Warszawie z dnia 9 września 2019 r., V ACa 289/19, Legalis nr 2271404; wyrok SO w Szczecinie z dnia 15 maja 2019 r., VIII GC 551/13, Legalis nr 2188793; wyrok SA w Warszawie z dnia 7 czerwca 2018 r., VII AGa 156/18, Legalis nr 1834724; wyrok SA w Białymstoku z dnia 19 kwietnia 2018, I AGa 63/18, Legalis nr 1820090; wyrok SO w Rzeszowie z dnia 4 kwietnia 2018 r., VI GC 298/17, Legalis nr 2121403; wyrok SA w Gdańsku z dnia 28 marca 2017 r., I ACa 782/16, Legalis nr 1674047; wyrok SO w Poznaniu z dnia 5 października 2016 r., XIV C 258/16, Legalis nr 2114055; wyrok SO w Białymstoku z dnia 30 września 2016 r., VII Ga 335/16, Legalis nr 1979692, Legalis nr 1979692; wyrok SA w Krakowie z dnia 12 stycznia 2016 r., I ACa 1413/15, Legalis nr 1435325; wyrok SO w Olsztynie z dnia 27 lipca 2017 r., V GC 64/15, Legalis nr 1984522; wyrok SN z dnia 24 czerwca 2015 r., II CSK 554/14, Legalis nr 1310191; wyrok SA w Szczecinie z dnia 30 marca 2015 r., I ACa 825/14, Legalis nr 1327299; wyrok SA w Warszawie z dnia 28 listopada 2014 r., I ACa 805/14, LEX nr 1667644; wyrok SR w Oławie z dnia 20 lutego 2014 r., VI C 577/13, Legalis nr 2171971; wyrok SN z dnia 24 września 2008 r., II CSK 118/08, OSNC 2009, nr 9, poz. 131 z glosą aprobującą K. Bilewskiej, Odpowiedzialność odszkodowawcza..., s. 1070-1073; wyrok SN z dnia 9 lutego 2006 r., V CSK 128/05, Monitor Prawniczy 2006, nr 5, s. 226.

18 Wyrok SA w Warszawie z dnia 9 września 2019 r., V ACa 289/19, Legalis nr 2271404; wyrok SN z dnia 8 listopada 2018 r., II CSK 587/17, Legalis nr 1847119; wyrok SA w Katowicach z dnia 6 grudnia 2017 r., V ACa 712/17, Legalis nr 1712719; wyrok SN z dnia 14 kwietnia 2016 r., II CSK 430/15, Legalis nr 1472302; wyrok SA w Krakowie z dnia 12 stycznia 2016 r., I ACa 1413/15, Legalis nr 1435325; wyrok SO w Łodzi z dnia 19 września 2014 r., X GC 888/13, Legalis nr 2077199; wyrok SA w Warszawie z dnia 18 sierpnia 2011 r., I ACa 54/11, Legalis 385358; wyrok SN z dnia 24 września 2008 r., II CSK 118/08, OSNC 2009, nr 9, poz. 131 z glosą aprobującą K. Bilewskiej, Odpowiedzialność odszkodowawcza..., s. 1070-1073. 
zresztą wypowiada się także większość przedstawicieli literatury ${ }^{19}$. Tym samym wywody przedstawione w rozważanym wyroku zdają się w tym zakresie spójnie nawiązywać do ustalonych już stanowisk. Wniosek ten w mojej ocenie jest jednak trafny tylko prima facie. Uwzględnienie bowiem całości argumentacji Sądu Najwyższego ujawnia jej pewną niekonsekwencję.

W omawianym orzeczeniu przyjęto bowiem, że tylko podmioty inne niż spółka mogą domagać się naprawienia szkody na zasadach ogólnych w ramach odesłania zawartego w art. 300 K.s.h. Podobne stanowisko prezentuje także część przedstawicieli literatury ${ }^{20}$, choć trafniejszy, jak sądzę, jest pogląd odmienny, zgodnie z którym powołany przepis w ogóle nie odnosi się do spółki ${ }^{21}$. Różnica ta nabiera istotnego znaczenia w świetle dalszych wywodów sformułowanych w glosowanym wyroku. Sąd Najwyższy stwierdził mianowicie, że syndyk nie jest osobą trzecią w rozumieniu art. 300 K.s.h. Tym samym powyższa interpretacja zdaje się wykluczać możliwość żądania przez syndyka w ramach reżimu odpowiedzialności deliktowej naprawienia szkody wyrządzonej spółce czynem niedozwolonym członka zarządu. Uszczerbek doznany w wyniku deliktu wspomnianego piastuna organu spółki podlegałby natomiast kompensacji jedynie na mocy art. 293 K.s.h., a więc w ramach odpowiedzialności kontraktowej.

Mając na uwadze zwięzłość uzasadnienia glosowanego wyroku, można by wywodzić, że syndyk nie jest wprawdzie osobą trzecią w rozumieniu art. 300 K.s.h., lecz i tak może domagać się naprawienia szkody na podstawie art. 415 K.c. Pogląd ten opierałby się na założeniu, zgodnie z którym art. 300 K.s.h. nie odnosi się do spółki, która stanowi z perspektywy prawa materialnego stronę postępowania prowadzonego przez syndyka. Powyższą konkluzję podważają jednak dalsze wywody Sądu Najwyższego, w których wykluczono występowanie w rozpatrywanej sprawie zbiegu roszczeń odszkodowawczych ex contractu i ex delicto. Tym samym stanowisko wyrażone w glosowanym orzeczeniu może stanowić punkt wyjścia do konstruowania, nietrafnego jak sądzę, poglądu, w świetle którego spółka i syndyk nie mogą żądać na podstawie art. 415 K.c. naprawienia szkody wyrządzonej przez członka zarządu.

19 A. Opalski, w: Kodeks spótek..., s. 1101; M. Rodzynkiewicz, Kodeks spółek handlowych. Komentarz, Warszawa 2018, s. 677-679; T. Szczurowski, Kodeks spółek..., 2020, art. 293, Nb. 7 [baza danych Legalis]. Odmiennie K. Bilewska, Glosa do wyroku SN z 15 czerwca 2005 r., IV CK 731/04, Orzecznictwo Sądów Polskich 2007, nr 9, poz. 103, s. 648; R. Szczęsny, Odpowiedzialność odszkodowawcza członków zarzadu, Prawo Spółek 2007, nr 3, s. 28, 31; T. Szczurowski, Kodeks spółek..., 2020, art. 300, Nb. 2 [baza danych Legalis].

20 K. Bilewska, Glosa do..., s. 648; R. Szczęsny, Odpowiedzialność odszkodowawcza..., s. 28, 31; T. Szczurowski, Kodeks spółek..., 2020, art. 300, Nb. 2 [baza danych Legalis].

21 A. Opalski, w: Kodeks spółek..., s. 1214; A. Szajkowski, M. Tarska, w: S. Sołtysiński i in., Kodeks spótek..., s. 985. 
IV.

Abstrahując od powyższej wątpliwości, należy zauważyć, że w glosowanym orzeczeniu Sąd Najwyższy trafnie zwrócił uwagę na krzyżowanie się zakresów zastosowania art. 293 K.s.h. oraz art. 415 K.c. w zw. z art. 300 K.s.h. Tym samym nie każde zachowanie członka zarządu sprzeczne $\mathrm{z}$ treścią stosunku organizacyjnego może być zakwalifikowane jako delikt. Niekiedy w orzecznictwie uznaje się wręcz, że zbieg roszczeń z art. 293 K.s.h. oraz art. 415 K.c. w zw. z art. 300 K.s.h. występuje jedynie wyjątkowo ${ }^{22}$. W konsekwencji wywodzenie roszczenia $z$ art. 293 K.s.h. albo z art. 415 K.c. w zw. z art. 300 K.s.h. nie jest obojętne dla dochodzenia naprawienia szkody. Z tej perspektywy istotnego znaczenia nabiera w szczególności bezprawność zachowania szkodzącego, która słusznie jest postrzegana jako element odróżniający reżim odpowiedzialności deliktowej i kontraktowej ${ }^{23}$. Za rozważeniem właśnie tej kwestii przemawia ponadto akcentowany w orzecznictwie pogląd, zgodnie z którym ratio legis art. 293 K.s.h. stanowi właśnie wąskie ujęcie bezprawności zachowania członka zarządu ${ }^{24}$, co zresztą spotkało się z akceptacją części doktryny ${ }^{25}$.

Z perspektywy odpowiedzialności kontraktowej bezprawność dłużnika polega na naruszeniu obowiązków składających się na treść zobowiązania. W art. 293 K.s.h. ustawodawca wskazuje zarazem, że członek zarządu ponosi wspomnianą odpowiedzialność w razie wyrządzenia spółce szkody przez działanie albo zaniechanie sprzeczne z ustawą albo umową spółki. Tym samym, przynajmniej prima facie, bezprawność wspomnianego funkcjonariusza jest ujęta w sposób węższy niż wynika to $\mathrm{z}$ art. 471 K.c. Trzeba jednak zaznaczyć, że zakres tego zawężenia jest przedmiotem sporu dotyczącego interpretacji przesłanki sprzeczności zachowania członka

22 Wyrok SA w Warszawie z dnia 9 września 2019 r., V ACa 289/19, Legalis nr 2271404.

23 K. Osajda, w: Kodeks cywilny. Komentarz, t. 3a, red. K. Osajda, Warszawa 2017, s. 822-823. Podobnie Z. Banaszczyk, P. Granecki, O istocie należytej staranności, Palestra 2002, nr 7-8, s. 16-17; G. Bieniek, J. Gudowski, w: Kodeks cywilny. Komentarz, t. 3. Zobowiązania. Część ogólna, red. J. Gudowski, Warszawa 2018, s. 985-986. Podobnie w kontekście odpowiedzialności członków zarządu za szkodę wyrządzoną spółce P. Błaszczyk, Odpowiedzialność odszkodowawcza menedżerów spółek za zawieranie umów opcji walutowych, Prawo Spółek 2009, nr 6, s. 4.

24 Wyrok SN z dnia 8 listopada 2018 r., II CSK 587/17, Legalis nr 1847119; wyrok SA w Szczecinie z dnia 30 marca 2015 r., I ACa 825/14, Legalis nr 1327299; wyrok SN z dnia 24 września 2008 r., II CSK 118/08, OSNC 2009, nr 9, poz. 131 z glosą aprobującą K. Bilewskiej, Odpowiedzialność odszkodowawcza..., Monitor Prawniczy 2009, nr 19, s. 1070-1073.

25 P. Błaszczyk, Koncepcja „biznesowej oceny sytuacji” na tle prawa polskiego (uwagi de lege lata i de lege ferenda), Państwo i Prawo 2012, nr 3, s. 83. Podobnie K. Bilewska, Odpowiedzialność odszkodowawcza..., s. 1071; M. Rodzynkiewicz, Kodeks spółek..., s. 676. Odmiennie R. Szczęsny, Odpowiedzialność odszkodowawcza..., s. 25-26, 31. 
zarządu z prawem ${ }^{26}$. Rozstrzygnięcie tej kontrowersji wykraczałoby jednak poza ramy niniejszego opracowania.

Należy natomiast zaznaczyć, że zachowanie sprzeczne z prawem kwalifikuje się jako bezprawne także $\mathrm{w}$ ramach reżimu odpowiedzialności deliktowej ${ }^{27}$. Spostrzeżenie to wymaga jednak uzupełnienia. Za bezprawne $\mathrm{z}$ perspektywy art. 415 K.c. uważa się bowiem tylko działanie albo zaniechanie, które narusza powszechny obowiązek, spoczywający na każdym bez względu na treść zobowiązania, jakie mogło wcześniej powstać między poszkodowanym i podmiotem zobowiązanym do naprawienia szkody ${ }^{28}$. Podobne stanowisko zostało również zaprezentowane $\mathrm{w}$ orzeczeniach dotyczących odpowiedzialności członka zarządu za szkodę wyrządzoną spółce ${ }^{29}$. Powstaje zatem pytanie, czy przewidziane przez prawodawcę obowiązki wymienionego piastuna organu spółki mogą być uznane za powszechne. Wspomniane nakazy i zakazy są wprawdzie wyrażone w aktach prawa powszechnie wiążącego. Niemniej ich adresatem jest tylko członek zarządu jako strona stosunku organizacyjnego.

Warto w tym kontekście wskazać na przyjęcie w glosowanym orzeczeniu, że zawieranie umów niekorzystnych dla spółki z podmiotem, który już wcześniej nie realizował wobec niej swoich zobowiązań, nie stanowiło deliktu członka zarządu. Zwięzłość stanowiska Sądu Najwyższego nie pozwala jednak na stwierdzenie, czy powyższa konkluzja wynika z wykluczenia możliwości dochodzenia przez syndyka naprawienia

26 Zamiast wielu zob. A. Opalski, w: Kodeks spółek..., s. 1102-1122 wraz z powołaną tam literaturą i orzecznictwem.

27 Z. Banaszczyk, w: Kodeks cywilny, t. 1. Komentarz. Art. 1-44910, red. K. Pietrzykowski, Warszawa 2018, s. 1409; G. Bieniek, J. Gudowski, w: Kodeks cywilny..., s. 590; W. Dubis, w: Kodeks cywilny. Komentarz, red. E. Gniewek, P. Machnikowski, Warszawa 2019, s. 882; B. Lanckoroński, w: Kodeks cywilny. Komentarz, t. 3a, red. K. Osajda, Warszawa 2018, s. 526; P. Machnikowski, Czyny niedozwolone, w: Prawo zobowiązań - część ogólna, t. 6, red. A. Olejniczak, Warszawa 2014, s. 413-414; A. Olejniczak, w: Kodeks cywilny, t. 3. Zobowiązania. Część szczególna, red. A. Kidyba, Warszawa 2014, s. 418; M. Zelek, w: Kodeks cywilny, t. 1. Komentarz. Art. 1-44911, red. M. Gutowski, Warszawa 2016, s. 1585-1586. Podobnie I. Długoszewska-Kruk, w: Kodeks cywilny. Komentarz, red. M. Załucki, Warszawa 2019, s. 983.

28 Z. Banaszczyk, w: Kodeks cywilny..., s. 1397-1398; G. Bieniek, J. Gudowski, w: Kodeks cywil$n y \ldots$.., s. 985-986; M. Chajda, w: Kodeks cywilny. Komentarz, red. M. Załucki, Warszawa 2019, s. 1020; B. Lanckoroński, w: Kodeks cywilny..., s. 518; A. Olejniczak, w: Kodeks cywilny..., s. 418; M. Safjan, w: Kodeks cywilny, t. 1. Komentarz. Art. 1-44910, red. K. Pietrzykowski, Warszawa 2018, s. 1552. Podobnie M. Wałachowska, w: Kodeks cywilny. Komentarz, t. 3. Zobowiązania. Część ogólna (art. 353-534), red. M. Habdas, M. Fras, Warszawa 2018, s. 616.

29 Wyrok SA w Warszawie z dnia 9 września 2019 r., V ACa 289/19, Legalis nr 2271404; wyrok SN z dnia 8 listopada 2018 r., II CSK 587/17, Legalis nr 1847119; wyrok SA w Łodzi z dnia 19 grudnia 2012 r., I ACa 946/12, Legalis nr 734298. Podobnie wyrok SA w Szczecinie z dnia 13 grudnia 2019 r., I ACa 160/19, Legalis nr 2301573. 
szkody w ramach reżimu odpowiedzialności deliktowej, czy też zachowanie członka zarządu nie naruszało żadnego powszechnego obowiązku. Z tej perspektywy wywodzenie roszczenia z art. 293 K.s.h. wydaje się zatem korzystniejsze dla syndyka, gdyż usuwa wątpliwości co do statusu obowiązku naruszonego przez członka zarządu.

Nie ulega ponadto wątpliwości, że nakazy i zakazy wynikające z postanowień umowy spółki nie kreują obowiązków powszechnych. Normy prawne zawarte $\mathrm{w}$ wymienionej umowie nie zaliczają się bowiem do norm prawa powszechnie wiążącego w świetle art. 87 Konstytucji Rzeczypospolitej Polskiej ${ }^{30}$. Niewykluczone wprawdzie, że naruszenie określonego postanowienia umowy spółki stanowi in casu także zachowanie bezprawne istotne z punktu widzenia art. 415 K.c. Niemniej nie można $z$ góry zakładać takiej tożsamości. W konsekwencji wywodzenie z art. 293 K.s.h. roszczenia syndyka o naprawienie szkody wydaje się ponownie korzystniejszym rozwiązaniem, gdyż pozwala w omawianym zakresie na szersze ujęcie klasy zachowań, za które odpowiedzialność ponosi członek zarządu.

Warto jednak zaznaczyć, że bezprawność zachowania danego podmiotu z perspektywy odpowiedzialności deliktowej może polegać nie tylko na naruszeniu normy prawnej, lecz także na naruszeniu innej normy postępowania ${ }^{31}$, wyprowadzanej przeważnie z zasad współżycia społecznego ${ }^{32}$. Konieczne jest jednak wtedy wskazanie dostatecznie silnego uzasadnienia, przemawiającego za uznaniem określonej normy postępowania za obowiązującą. Tymczasem w art. 293 K.s.h. ustawodawca nie wymienia zasad współżycia społecznego lub dobrych obyczajów. W powołanym przepisie nie użyto też ogólnego wyrażenia „bezprawność”. W konsekwencji w orzecznictwie przyjmuje się, że członek zarządu nie ponosi odpowiedzialności przewidzianej w art. 293 K.s.h. w razie naruszenia normy postępowania wynikającej z zasad współżycia społecznego ${ }^{33}$. Wniosek ten spotkał się również z aprobatą w literaturze ${ }^{34}$.

30 Konstytucja Rzeczypospolitej Polskiej z dnia 2 kwietnia 1997 r., Dz. U. z 1997 r. Nr 78 poz. 483 z późn. $\mathrm{zm}$.

31 P. Machnikowski, Czyny niedozwolone..., s. 411-412.

32 Z. Banaszczyk, w: Kodeks cywilny..., s. 1409; G. Bieniek, J. Gudowski, w: Kodeks cywilny ..., s. 590; I. Długoszewska-Kruk, w: Kodeks cywilny..., s. 983; W. Dubis, w: Kodeks cywilny..., s. 882-883; B. Lanckoroński, w: Kodeks cywilny..., s. 526; A. Olejniczak, w: Kodeks cywilny..., s. 418-419; M. Wałachowska, w: Kodeks cywilny..., s. 406-407; M. Zelek, w: Kodeks cywilny..., s. 1586.

33 Wyrok SA w Krakowie z dnia 9 października 2018 r., I AGa 347/18, LEX nr 2692753; wyrok SA w Krakowie z dnia 12 stycznia 2016 r., I ACa 1413/15, Legalis nr 1435325; wyrok SA w Warszawie z dnia 28 listopada 2014 r., I ACa 805/14, LEX nr 1667644.

34 K. Bilewska, Glosa do..., s. 647; P. Błaszczyk, Przesłanka bezprawności w ramach odpowiedzialności odszkodowawczej menedżerów spółek, Monitor Prawniczy 2012, nr 1, s. 48; A. Guzewicz, M. Jagodziński, Przesłanki odpowiedzialności członków zarzadu w świetle art. 293 i art. 483 k.s.h. - de lege lata i de lege ferenda, Przegląd Prawa Handlowego 2013, nr 11, s. 48; K. Strzelczyk, w: Kodeks spólek handlowych. Komentarz, t. 3. Tytuł III. Spółki kapitałowe. Dział II. Spółka akcyjna, red. T. Siemiątkowski, 
Tym samym w powyższym zakresie odpowiedzialność na podstawie art. 415 K.c. w zw. z art. 300 K.s.h. byłaby szersza niż odpowiedzialność przewidziana w art. 293 K.s.h. Niemniej praktyczne znaczenie możliwości dochodzenia przez syndyka naprawienia szkody wyrządzonej spółce przez działanie albo zaniechanie członka zarządu sprzeczne $\mathrm{z}$ normą postępowania wynikającą z zasad współżycia społecznego wydaje się ograniczone. Ustawodawca wyklucza bowiem expressis verbis $\mathrm{w}$ art. 209-211 K.s.h. podejmowanie przez członka zarządu najbardziej typowych nieetycznych zachowań względem spółki.

\section{V.}

Analizując stanowisko przedstawione w glosowanym orzeczeniu, warto jeszcze zwrócić uwagę na kwestię przedawnienia. Zgodnie bowiem z art. 297 K.s.h. roszczenie o naprawienie szkody wyrządzonej przez członka zarządu przedawnia się w ramach reżimu odpowiedzialności kontraktowej z upływem 3 lat od dnia, w którym spółka dowiedziała się o szkodzie i o osobie obowiązanej do jej naprawienia. W każdym jednak przypadku roszczenie to przedawnia się z upływem 10 lat od dnia, w którym nastąpiło zdarzenie wyrządzające szkodę.

Ustawodawca nie określił natomiast w przepisach K.s.h. terminu przedawnienia dla roszczeń o naprawienie szkody wyrządzonej przez członka zarządu w ramach reżimu odpowiedzialności deliktowej. Na podstawie odesłania zawartego w art. 300 K.s.h. zastosowanie znajduje jednak wtedy art. $442^{1}$ K.c. Przepis ten reguluje termin przedawnienia co do zasady podobnie do art. 297 K.s.h. W art. $442^{1}$ $\$ 1$ K.c. wskazano bowiem jedynie dodatkowo, że bieg rozważanego terminu rozpoczyna się już w chwili, w której przy zachowaniu należytej staranności poszkodowany mógł dowiedzieć się o szkodzie i o osobie obowiązanej do jej naprawienia. Tym samym, mimo uregulowania $\mathrm{w}$ różnych przepisach kwestii przedawnienia roszczenia z art. 293 K.s.h. i roszczenia z art. 415 K.c. w zw. z art. 300 K.s.h., glosowane orzeczenie zdaje się $\mathrm{w}$ tym zakresie nie wprowadzać zasadniczej zmiany. Co więcej, wywodzenie roszczenia z art. 293 K.s.h. może in casu być rozwiązaniem korzystniejszym dla syndyka, gdyż potencjalnie wydłuża okres, w którym członkowi zarządu nie przysługuje zarzut $\mathrm{z}$ art. $117 \$ 2$ K.c.

R. Potrzeszcz, Warszawa 2012, s. 1373; T. Szczurowski, Kodeks spółek..., 2020, art. 293, Nb. 15 [baza danych Legalis]. Odmiennie A. Chełkowska, Regulacja odpowiedzialności odszkodowawczej członków zarzadu z perspektywy zasad ładu korporacyjnego, Przegląd Prawa Handlowego 2016, nr 10, s. 34. Podobnie zdaje się A. Opalski, w: Kodeks spótek..., s. 1109. 
Trzeba jednak zauważyć, że termin przedawnienia roszczenia $\mathrm{z}$ art. 415 K.c. w zw. z art. 300 K.s.h. ulega znaczącej modyfikacji na mocy art. $442^{1} \$ 2$ K.c., jeżeli szkoda wynikła ze zbrodni lub występku. W takim przypadku omawiane roszczenie ulega bowiem przedawnieniu dopiero $\mathrm{z}$ upływem 20 lat od dnia popełnienia przestępstwa bez względu na to, kiedy poszkodowany dowiedział się o szkodzie i o osobie obowiązanej do jej naprawienia. Podobne rozwiązanie nie zostało natomiast przewidziane w art. 297 K.s.h. Spostrzeżenie to ma istotne znaczenie, gdyż w glosowanym orzeczeniu Sąd Najwyższy zdaje się przyjmować, że syndyk nie jest osobą trzecią w rozumieniu art. 300 K.s.h., wobec czego podmiot ten nie mógłby również domagać się naprawienia szkody wyrządzonej czynem niedozwolonym członka zarządu. Konsekwentnie zatem należałoby uznać, że termin przedawnienia roszczenia syndyka o naprawienie szkody wyrządzonej w wyniku popełnienia przez członka zarządu zbrodni lub występku nie ulega wydłużeniu. Stanowisko to wydaje się jednak trudne do zaakceptowania. Prowadzi ono bowiem do nieuzasadnionego zróżnicowania intensywności ochrony prawnej podmiotów prawa cywilnego.

Sądzę, że należałoby raczej opowiedzieć się konsekwentnie za konkurencją roszczenia $\mathrm{z}$ art. 293 K.s.h. i roszczenia $\mathrm{z}$ art. 415 K.c. w zw. $\mathrm{z}$ art. 300 K.s.h. wraz z wynikającymi z tego konsekwencjami w zakresie bezprawności, rozkładu ciężaru dowodu winy dłużnika oraz terminu przedawnienia. W takim ujęciu termin przedawnienia roszczenia syndyka o naprawienie szkody wyrządzonej spółce w następstwie zbrodni lub występku członka zarządu podlegałby wydłużeniu zgodnie $\mathrm{z}$ art. $442^{1} \S 2$ K.c.

VI.

Z toku dotychczasowych rozważań wynika, że stanowisko wyrażone w glosowanym orzeczeniu oddziałuje nie tylko na kwestię legitymacji syndyka. W wyroku z dnia 8 maja 2019 r. Sąd Najwyższy wywiódł bowiem z art. 293 K.s.h. roszczenie wspomnianego podmiotu o naprawienie szkody wyrządzonej spółce przez członka zarządu. Tym samym zmianie uległa przyjmowana wcześniej w judykaturze podstawa powyższego żądania. Modyfikacja ta ma doniosłe znaczenie, gdyż w świetle omawianego wyroku syndyk może domagać się naprawienia szkody w ramach reżimu odpowiedzialności kontraktowej, a nie jak poprzednio podnoszono - tylko w ramach reżimu odpowiedzialności deliktowej. Konsekwentnie zatem wyrok z dnia 8 maja 2019 r. ma wpływ na ujmowanie bezprawności zachowania członka zarządu, rozkład ciężaru dowodu winy tego piastuna organu spółki, a także prze- 
dawnienie roszczenia odszkodowawczego. Glosowane orzeczenie nie jest przy tym w pełni wolne od wątpliwości, związanych w szczególności z wyłączeniem stosowania art. 300 K.s.h. do syndyka przy jednoczesnym uznaniu, że tylko podmioty objęte odesłaniem zawartym w powołanym przepisie mogą dochodzić naprawienia szkody w ramach reżimu odpowiedzialności deliktowej.

\section{Bibliografia}

Banaszczyk Z., w: Kodeks cywilny, t. 1. Komentarz. Art. 1-44910, red. K. Pietrzykowski, Warszawa 2018.

Banaszczyk Z., Granecki P., O istocie należytej staranności, Palestra 2002, nr 7-8.

Bieniek G., Gudowski J., w: Kodeks cywilny. Komentarz, t. 3. Zobowiazania. Część ogólna, red. J. Gudowski, Warszawa 2018.

Bilewska K., Glosa do wyroku SN z 15 czerwca 2005 r., IV CK 731/04, Orzecznictwo Sądów Polskich 2007, nr 9.

Bilewska K., Odpowiedzialność odszkodowawcza członków zarzadu spótki z o.o. jako odpowiedzialność ex contractu, Monitor Prawniczy 2009, nr 19.

Błaszczyk P., Koncepcja „biznesowej oceny sytuacji” na tle prawa polskiego (uwagi de lege lata i de lege ferenda), Państwo i Prawo 2012, nr 3.

Błaszczyk P., Odpowiedzialność odszkodowawcza menedżerów spótek za zawieranie umów opcji walutowych, Prawo Spółek 2009, nr 6.

Błaszczyk P., Przesłanka bezprawności w ramach odpowiedzialności odszkodowawczej menedżerów spótek, Monitor Prawniczy 2012, nr 1.

Chajda M., w: Kodeks cywilny. Komentarz, red. M. Załucki, Warszawa 2019.

Chełkowska A., Regulacja odpowiedzialności odszkodowawczej członków zarzadu z perspektywy zasad ładu korporacyjnego, Przegląd Prawa Handlowego 2016, nr 10.

Długoszewska-Kruk I., w: Kodeks cywilny. Komentarz, red. M. Załucki, Warszawa 2019.

Dubis W., w: Kodeks cywilny. Komentarz, red. E. Gniewek, P. Machnikowski, Warszawa 2019.

Guzewicz A., Jagodziński M., Przesłanki odpowiedzialności członków zarządu w świetle art. 293 i art. 483 k.s.h. - de lege lata $i$ de lege ferenda, Przegląd Prawa Handlowego 2013, nr 11.

Kidyba A., Kodeks spótek handlowych, t. 1. Komentarz do art. 1-300, Warszawa 2020.

Lanckoroński B., w: Kodeks cywilny. Komentarz, t. 3a, red. K. Osajda, Warszawa 2018.

Machnikowski P., Czyny niedozwolone, w: Prawo zobowiązań - część ogólna, t. 6, red. A. Olejniczak, Warszawa 2014.

Olejniczak A., w: Kodeks cywilny, t. 3. Zobowiazania. Część szczególna, red. A. Kidyba, Warszawa 2014.

Opalski A., w: Kodeks spótek handlowych, t. 2b. Spótka z ograniczoną odpowiedzialnością. Komentarz. Art. 227-300, red. A. Opalski, Warszawa 2018.

Osajda K., w: Kodeks cywilny. Komentarz, t. 3a, red. K. Osajda, Warszawa 2017.

Pabis R., w: J. Bieniak i in., Kodeks spółek handlowych. Komentarz, Warszawa 2017. 
Popardowski P., O spółkach handlowych w najnowszym orzecznictwie Sądu Najwyższego przeglą orzecznictwa, Glosa 2019, nr 4.

Radwan-Röhrenschef M., Odpowiedzialność cywilnoprawna członków zarządu spółek kapitałowych, Monitor Prawniczy 1999, nr 6.

Rodzynkiewicz M., Kodeks spółek handlowych. Komentarz, Warszawa 2018.

Safjan M., w: Kodeks cywilny, t. 1. Komentarz. Art. 1-44910, red. K. Pietrzykowski, Warszawa 2018.

Strzelczyk K., w: Kodeks spółek handlowych. Komentarz, t. 3. Tytuł III. Spółki kapitałowe. Dział II. Spółka akcyjna, red. T. Siemiątkowski, R. Potrzeszcz, Warszawa 2012.

Szajkowski A., Tarska M., w: S. Sołtysiński i in., Kodeks spółek handlowych, t. 2. Spółka z ograniczoną odpowiedzialnością. Komentarz do artykułów 151-399, Warszawa 2014.

Szczęsny R., Odpowiedzialność odszkodowawcza członków zarządu, Prawo Spółek 2007, nr 3.

Szczurowski T., w: Kodeks spółek handlowych, red. Z. Jara, 2020 [baza danych Legalis].

Wałachowska M., w: Kodeks cywilny. Komentarz, t. 3. Zobowiązania. Część ogólna (art. 353-534), red. M. Habdas, M. Fras, Warszawa 2018.

Zelek M., w: Kodeks cywilny, t. 1. Komentarz. Art. 1-44911, red. M. Gutowski, Warszawa 2016. 
